\title{
Analisis Tingkat Kerusakan Tanaman Jati (Tectona grandis L.f) Akibat Serangan Hama di Kelurahan Klamalu Distrik Mariat Kabupaten Sorong
}

\author{
Analysis of Damage Levels of Teak Plants (Tectonagrandis L.f) Due to Pest Attack in Klamalu Village, \\ Mariat District, Sorong Regency \\ MAYA PATTIWAEL ${ }^{1}$ \\ ${ }^{1)}$ Program Studi Kehutanan Fakultas Pertanian Universitas Victory Sorong \\ Jl. Basuki Rahmat km. 11,5 Sorong Papua Barat 98419 \\ Email : mayapattiwael@yahoo.com
}

\begin{abstract}
ABSTRAK
Jati (Tectona grandis L.f) merupakan salah satu tanaman tropis yang mempunyai nilai ekonomis tinggi. Tanaman Jati juga sering diserang oleh berbagai jenis hama sehingga mengakibatkan terjadinya penurunan kualitas dan kuantitas pertumbuhan maupun hasilnya. Penelitian ini dilakukan bertujuan untuk mengidentifikasi jenis-jenis hama yang merusak bagian daun pada tanaman Jati dan menentukan intensitas kerusakan serta frekuensi serangan hama pada tanaman Jati yang berada di Kelurahan Klamalu Distrik Mariat Kabupaten Sorong. Pengambilan data dilakukan dengan membagi 5 jalur secara acak sederhana, setiap plot diambil sampel sebanyak 5 tanaman. Hasil penelitian didapatkan beberapa jenis hama yang menyerang tanaman Jati yaitu belalang, kutu daun, ulat daun jati, dan kutu putih, dengan rata-rata intensitas kerusakan akibat serangan hama belalang $28,93 \%$ tergolong kriteria rusak sedang, serangan hama ulat daun $22,53 \%$ tergolong kriteria rusak ringan, serangan hama kutu putih $6,8 \%$ tergolong kriteria rusak ringan dan serangan hama kutu daun 5,7\% tergolong kriteria rusak ringan. Frekuensi serangan untuk masing-masing jenis hama adalah Hama Belalang 35,2\%, Hama Ulat Daun Jati 30,4\%, Hama Kutu Putih 8,8\% dan Hama Kutu Daun sebesar 4\%.
\end{abstract}

Kata kunci : Hama, jati, Kerusakan

\begin{abstract}
ABSTRCT
Teak (Tectona grandis L.f) is one of the tropical plants that has high economic value. Teak plants are also often attacked by various types of pests, which results in a decrease in the quality and quantity of growth and yield. This research was conducted aimed at identifying the types of pests that damage the leaves of teak plants and determine the intensity of damage and frequency of pest attacks on teak plants located in Klamalu Village, Mariat District, Sorong Regency. Data retrieval is done by dividing 5 simple random lines, 5 plots taken as samples. The results showed several types of pests that attacked teak plants namely grasshoppers, aphids, teak leaf caterpillars, and white mites, with an average damage intensity due to the attack of locust pests $28.93 \%$ classified as moderate damage, caterpillar pest attack $22.53 \%$ was classified as a criterion of mild damage, $6.8 \%$ white flea pest attacks classified as criteria for minor damage and infestation attacks $5.7 \%$ were classified as criteria for minor damage. The frequency of attacks for each type of pest is Grasshopper Pests 35.2\%, Teak Leaf Caterpillar Pests 30.4\%, White Louse Pests $8.8 \%$ and Leaf Louse Pests by $4 \%$
\end{abstract}

Keywords: Pests, Teak, Damage 


\section{PENDAHULUAN}

Suatu tanaman dikatakan sehat apabila tanaman tersebut memiliki pertumbuhan yang baik dan tidak mengalami penyimpangan kesehatan pada seluruh atau sebagian dari organorgannya, yang dapat menimbulkan kerugian bagi tanaman tersebut (Agrios, 1969 dalam Pracaya, 2003). Hal tersebut dapat terjadi pada semua tanaman termasuk tanaman kehutanan. Dalam upaya untuk memaksimalkan fungsi hutan terkadang muncul factor-faktor yang dapat menjadi faktor pembatas, baik yang disengaja maupun yang tidak disengaja. Oleh karena itu, penyelamatan fungsi hutan dan perlindunganya harus dilakukan untuk mencegah dan meminimalkan kerusakan hutan, sehingga manfaat ekologis dan ekonomis dapat tercapai.

Salah satu penyebab terjadinya kerusakan pada tanaman adalah munculnya serangan hama. Hama adalah perusak tanaman pada akar, batang, daun atau bagian tanaman lainnya sehingga tanaman tidak dapat tumbuh dengan sempurna atau mati (Sumardi dan Widyastuti, 2007). Hama juga dapat diartikan sebagai semua organisme hidup yang dapat menimbulkan kerusakan pada biji, bibit dan tanaman. Serangga merupakan kelompok hama paling berat yang menyebabkan kerusakan hutan. Permasalahan tentang serangan hama ini bukan hanya terjadi pada biji tapi juga terhadap tanaman muda, tegakan bahkan sampai pada hasil hutan sekalipun (Hidayat, et al.,2014).

Jati merupakan salah satu tanaman tropis yang mempunyai nilai ekonomis yang tinggi, karena kayunya tergolong kayu serbaguna dan merupakan salah satu kayu perdagangan yang memiliki kualitas kayu sangat bagus, sangat disukai dan memiliki permintaan sangat tinggi (Hidayat, et al.,2014). Dalam pertumbuhannya, tanaman Jati juga sering diserang oleh berbagai jenis hama sehingga mengakibatkan terjadinya penurunan kualitas dan kuantitas pertumbuhan maupun hasilnya serta menimbulkan kerugian yang cukup serius (Sumardi dan Widyastuti, 2007).

Beberapa jenis hama yang diketahui menyerang tanaman Jati di Indonesia dapat dilihat pada Tabel 1.

Tabel 1. Jenis Hama Yang Menyerang Tanaman Jati Di Indonesia (Nair, 2000)

\begin{tabular}{|c|c|c|c|}
\hline No & Jenis Hama & NamaUmum & Serangan \\
\hline 1. & $\begin{array}{l}\text { Valanga } \\
\text { nigricornis }\end{array}$ & Belalang kayu & Daun \\
\hline 2. & Xyleutes ceramica & $\begin{array}{l}\text { Ulat penggerek } \\
\text { batang }\end{array}$ & $\begin{array}{l}\text { Batang } \\
\text { pohon }\end{array}$ \\
\hline 3. & Hyblaea puera & Ulat daun Jati & Daun \\
\hline 4. & $\begin{array}{l}\text { Neotermes } \\
\text { tectonae }\end{array}$ & $\begin{array}{l}\text { Rayap pohon } \\
\text { atau Rayap kayu } \\
\text { basah }\end{array}$ & Batang \\
\hline 5. & $\begin{array}{l}\text { Paliga } \\
\text { damastesalis } \\
\text { (dikenal juga } \\
\text { dengan nama } \\
\text { Pyrausta } \\
\text { machaeralis) }\end{array}$ & Ulat daun Jati & Daun \\
\hline 6. & $\begin{array}{l}\text { Xyleborus } \\
\text { destruens }\end{array}$ & $\begin{array}{l}\text { Kumbang bubuk } \\
\text { basah }\end{array}$ & Batang \\
\hline
\end{tabular}

Di Papua Barat, tanaman jati dapat dijumpai di beberapa lokasi yang berada di wilayah Kabupaten Sorong, salah satunya adalah di Distrik Mariat Kelurahan Klamalu. Sama halnya dengan keadaan Tanaman Jati pada umumnya karena Tanaman Jati di daerah ini juga mengalami serangan hama yang menyebabkan 
kerusakan pada bagian-bagian tanaman berupa pucuk yang mengering, bekas gigitan pada daun dan lain sebagainya. Berdasarkan permasalahan tersebut, maka dilakukan penelitian yang bertujuan untuk mengidentifikasi jenis-jenis hamayang merusak bagian daun pada tanaman Jati dan menentukan intensitas kerusakan serta frekuensi serangan hama pada tanaman Jati di Kelurahan Klamalu Distrik Mariat Kabupaten Sorong

\section{METODOLOGI}

\section{Alat dan Bahan}

Peralatan yang digunakan dalam penelitian ini adalah kamera, kompas, meter rol, alat tulismenulis, dan buku pengenalan jenis hama-hama hutan. Bahan yang digunakan adalah hama tanaman jati dan tanaman jati yang langsung ditemukan di lapangan.

\section{Metode Penelitian}

Pengambilan data dilakukan pada areal yang ditanam dengan tanaman jati yang dibagi dalam 5 jalur yang ditentukan secara acak sederhana (Simple Random Sampling). Setiap jalur dibagi lagi ke dalam plot-plot yang berukuran sama dan dari setiap plot tersebut, diambil sampel sebanyak 5 tanaman. Identifikasi gejala dilakukan dengan melihat perubahan fisik yang terjadi pada bagian daun dari tanaman Jati, seperti daun yang berlubang, pucuk yang terpotong atau keriting, dan lainlain.Pengambilan tanaman contoh untuk menghitung frekuensi serangan adalah jumlah tanaman pada areal penelitian secara keseluruhan.

\section{Analisis Data}

Untuk mengetahui frekuensi serangan hama pada tanaman, dihitung dengan menggunakan rumus (Nurariaty, dkk, 2008 dalam Hidayat, et al., 2014) :

Frek. Serangan $=\frac{\sum \text { Tan yg diserang } \& \text { mati }}{\sum \text { Pohon pengamatan }} \times 100 \%$

Intensitas serangan dihitung dengan menggunakan rumus de Guzman (1985) yang dimodifikasi Mardji (2000) dalam Sumardi dan Widyastuti, 2007) sebagai berikut :

$$
I=\frac{X_{1} Y_{1}+X_{2} Y_{2}+X_{3} Y_{3}+X_{4} Y_{4}}{X Y} \times 100 \%
$$

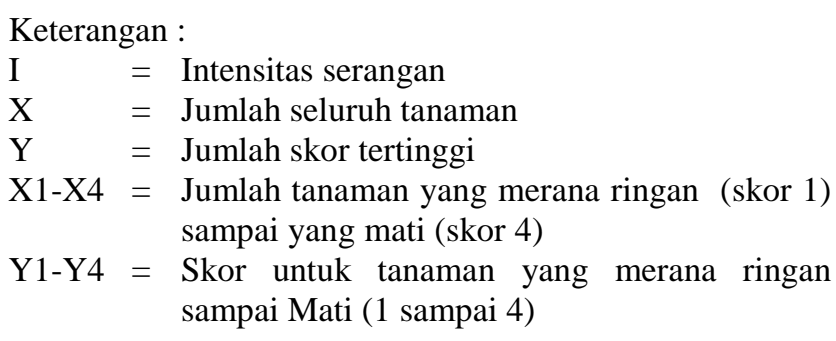

Setelah diperoleh nilai intensitas serangan, maka kemudian ditentukan besarnya akibat yang ditimbulkan oleh serangan hama. Cara menentukan kondisi tanaman akibat serangan hama dapat dilihat pada Tabel 2.

Tabel 2. Cara Menentukan Kondisi Tanaman Akibat Serangan Hama (Leatemia dan Rumthe, 2011 dalam Hidayat et al., 2014)

\begin{tabular}{cc}
\hline $\begin{array}{c}\text { Intensitas Serangan } \\
(\boldsymbol{\%})\end{array}$ & $\begin{array}{c}\text { Kondisi Tegakan / } \\
\text { Tingkat Kerusakan }\end{array}$ \\
\hline $0-1$ & Normal \\
$>1-25$ & Rusak ringan \\
$>25-50$ & Rusak sedang \\
$>50-75$ & Rusak berat \\
$>75-100$ & Mati \\
\hline
\end{tabular}




\section{HASIL DAN PEMBAHASAN}

\section{Jenis Hama dan Serangannya}

Dari hasil pengamatan langsung di lapangan, ditemukan beberapa jenis hama yang menyerang tanaman Jati di Kelurahan Klamalu Distrik Mariat Kabupaten Sorong, seperti data pada Tabel 3, yaitu ulat daun jati, kutu daun, belalang, dan kutu putih.

Tabel 3. Hama Yang Menyerang Tanaman Jati di Kelurahan Malawili Distrik Aimas Kabupaten Sorong

\begin{tabular}{|c|c|c|}
\hline $\begin{array}{l}\text { Jenis } \\
\text { Hama }\end{array}$ & $\begin{array}{l}\text { Nama } \\
\text { Ilmiah }\end{array}$ & Keterangan \\
\hline $\begin{array}{l}\text { Ulat } \\
\text { daun jati }\end{array}$ & $\begin{array}{l}\text { Hyblaea } \\
\text { puera }\end{array}$ & $\begin{array}{l}\text { Memakan daun } \\
\text { sampai tinggal tulang } \\
\text { daun saja }\end{array}$ \\
\hline $\begin{array}{l}\text { Kutu } \\
\text { daun }\end{array}$ & Aphis sp & $\begin{array}{l}\text { Menyerang daun } \\
\text { dengan menghisap } \\
\text { cairan daun }\end{array}$ \\
\hline Belalang & $\begin{array}{l}\text { Valanga } \\
\text { nigricornis }\end{array}$ & $\begin{array}{l}\text { Memakan bagian daun } \\
\text { dan tulang daun }\end{array}$ \\
\hline $\begin{array}{l}\text { Kutu } \\
\text { putih }\end{array}$ & $\begin{array}{l}\text { Bemisia } \\
\text { tabaci }\end{array}$ & $\begin{array}{l}\text { Menyebabkan pucuk } \\
\text { berkerut }\end{array}$ \\
\hline
\end{tabular}

Dari Tabel 3 terlihat bahwa semua jenis hama yang ditemukan termasuk ke dalam golongan hama pemakan daun. Akibat yang ditimbulkan dari hama-hama tersebut adalah adanya daun yang berlubang dan ada pula bagian daun yang dimakan sampai tinggal tulang daunnya saja.

\section{Ulat daun jati (Hyblaea puera)}

Ulat daun jati ini ditemukan pada daun yang menggulung. Diketahui bahwa ulat daun jati memakan semua jaringan daun, mulai dari bagian daun yang lunak sampai tinggal urat daun dan tulang saja (Umarela dan Karepseina, 2011). Hama ini biasanya menyerang pada awal musim penghujan. Kondisi cuaca di Kabupaten sorong saat ini tidak menentu. Musim hujan dan panas silih berganti. Haltersebut kemungkinan yang menyebabkan hama-hama pada tanaman jati semakin banyak. Terbukti dengan ditemukannya sebagian besar daun tanaman Jati berada dalam kondisi berlubang-lubang karena serangan hama. Apabila tingkat serangan sudah tinggi, maka perlu dilakukan pengendalian dengan menyemprot insektisida
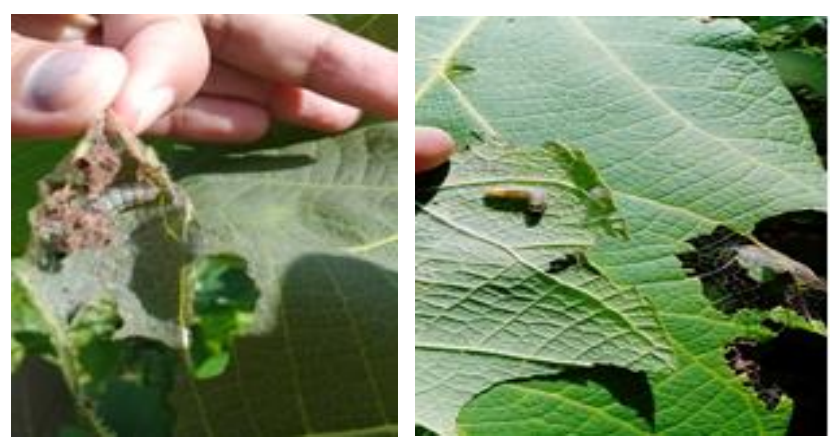

Gambar 1. Hama ulat jati yang ditemukan membungkus diri pada daun jati

\section{Kutu daun (Aphids sp)}

Kutu daun yang berumur dewasa biasanya menyerang pucuk tanaman daun jati. Cairan pucuk tanaman biasanya dihisap hingga daun menjadi berkerut, menguning yang kemudian mengering dan gugur. Apabila cairan pada bagian pucuk telah habis, maka kutu daun akan berpindah menyerang daun yang lebih tua yang masih bisa dihisap cairannya. Serangan kutu daun terjadi semakin besar pada musim kemarau, tetapi pada musim hujan serangannya agak sedikit terhambat karena kekuatan menghisap jadi berkurang, yang disebabkan oleh kekuatan air hujan yang dapat merontokan kutu daun yang menempel pada daun (Hidayat,et al., 2014). Hal ini sesuai dengan yang terjadi di lokasi 
pengamatan. Gejala serangan hama ini tidak begitu nampak karena faktor cuaca yang tidak menentu. Kemungkinan kehadiran hama ini tidak dalam jumlah yang banyak, sehingga jarang ditemukan daun jati yang menunjukkan gejala diserang hama kutu daun.

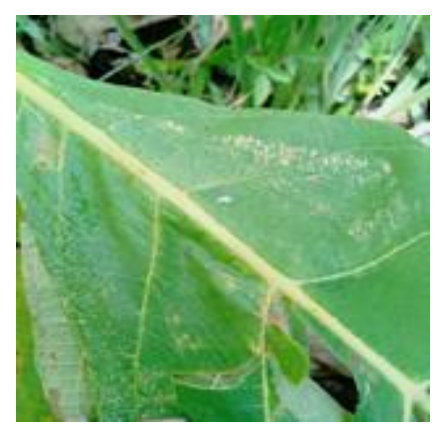

Gambar 2. Daun jati yang mulai tampak menguning

\section{Belalang (Valanga nigricornis)}

Belalang adalah salah satu anggota dari ordo Orthoptera yang dikenal sebagai pemakan tumbuhan. Ordo ini memiliki mulut bertipe penggigit dan pengunyah (Da Lopes, 2017) yang memudahkannya dalam memakan daun-daun tanaman. Siklus hidup belalang terdiri atas telur, nimfa, dan imago. Belalang (masih muda dan dewasa) biasanya memakan daun-daun tanaman jati pada bagian tepi daun sampai tulang-tulang daun sehingga menimbulkan lubang-lubang pada daun (Hidayat, et al., 2014). Pada stadium nimfa dan imago biasanya bersifat merusak tumbuhan (Da Lopes, 2017). Kerusakan daun secara langsung akan pengaruh terhadap produktifitas tanaman yang diserang. Jika serangan tanaman ini serius, daun tanaman jati yang diserang akan rusak bahkan habis dimakan. Jika populasinya banyak dan belalang sedang dalam keadaan kelaparan, hama ini bisa menghabiskan daundaun sekaligus dengan tulang- tulangnya.

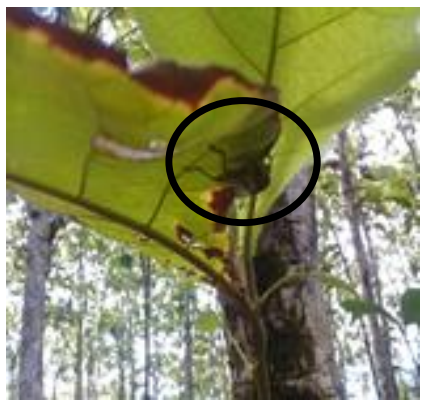

(a)

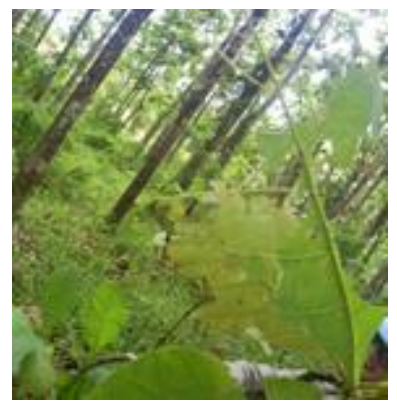

(b)
Gambar (3a) Belalang di daun Jati; (3b) Daun jati yang dimakan belalang.

Pada lokasi penelitian, terlihat beberapa belalang yang sedang memakan daun tanaman jati.Daun yang dimakan tidak hanya pada satu titik saja, tapi berpindah-pindah pada satu daun itu, seolah-olah mencari bagian yang enak untuk dimakan. Hal ini sesuai dengan yang dikemukakan oleh Rahmanto dan lestari (2013) dalam Hidayat, et al (2014), belalang hanya memakan sebagian daun (folium) dan bagian perbagian tidak secara menyeluruh pada satu daun

\section{Hama Kutu Putih (Bemisia tabaci)}

Hama ini biasa menyerang setiap saat.Bagian tanaman yang diserang adalah pucuk (jaringan meristematis). Pucuk daun yang terserang menjadi keriting sehingga tumbuh abnormal. 


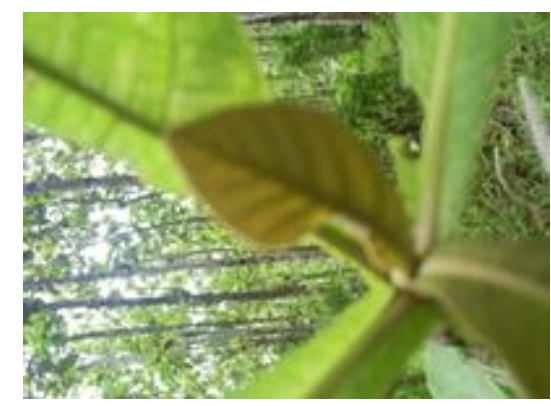

Gambar 4. Pucuk tanaman yang terlihat mengerut

Selain 4 jenis hama yang telah disebutkan, di lokasi penelitian juga ditemukan Capung (Pantala flavescens), Kumbang Koksi (Coccinella transversalis) dan Kupu-kupu kuning (Eurema spp), Ketiga jenis ini tidak terlihat merusak daun jati. Khusus untuk Capung (Pantala flavescens) dan Kupu-kupu kuning (Eurema spp), terlihat berpindah-pindah dengan cepat dari satu daun ke daun lainnya termasuk ke daun jati, tapi tidak terlihat gerakan untuk merusak daun.Selain itu, jumlahnya cukup banyak di areal penelitian.

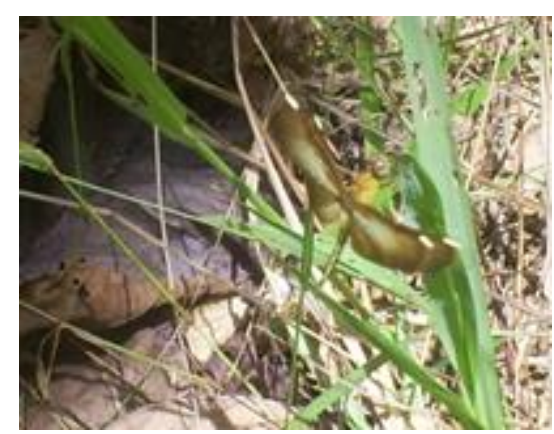

Gambar 5.Capung

Kupu-kupu kuning terlihat berpindah begitu cepat dari satu daun ke daun lainnya. Bahkan sempat hinggap pada daun jati, namun tidak terlihat melakukan gerakan memakan daun jati. Hal ini disebabkan karena jenis serangga yang termasuk ordo Lepidoptera ini pada saat sudah menjadi imago, alat mulutnya bertipe penghisap sehingga hanya menghisap nektar atau madu dari bunga-bungaan (Da Lopes, 2017).

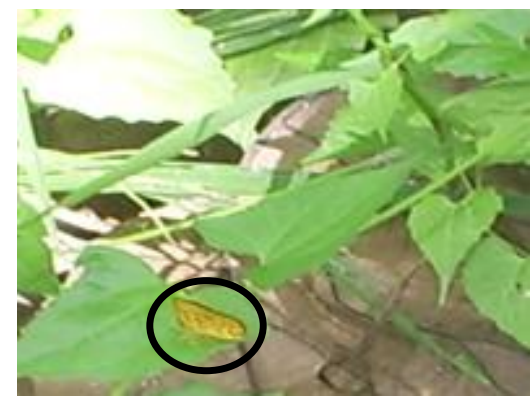

Gambar 6. Kupu-kupu Kuning

Kumbang Koksi berasal dari ordo Coleoptera. Sebagian anggota-anggotanya ada yang bertindak sebagai hama tanaman, namun ada juga yang bertindak sebagai predator (pemangsa) bagi serangga lain. Khusus untuk jenis Coccinella transversalis dikenal sebagai jenis serangga yang makanannya seperti kutu daun (Aphids). Di lokasi penelitian, jenis ini ditemukan berada di belakang daun dan tidak terlihat sama sekali merusak daun.

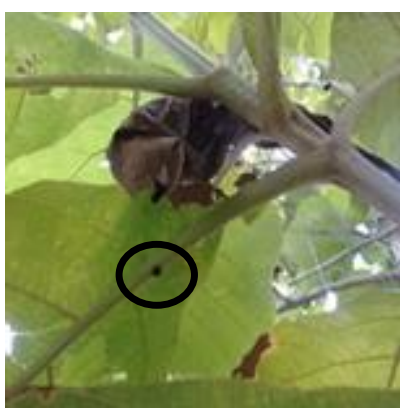

Gambar 7. Kumbang Koksi transversalis)

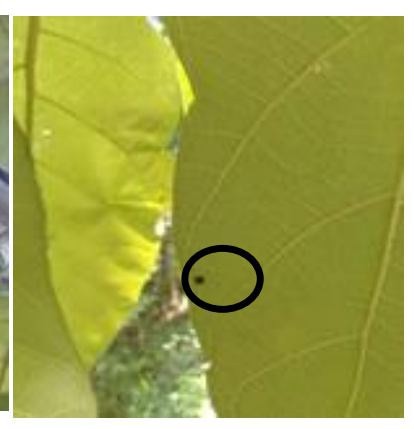

(Coccinella

\section{Kerusakan Tanaman}

\section{Intensitas Kerusakan}

Pada Tabel 4 dapat dilihat rata-rata intensitas kerusakan tanaman Jati akibat serangan hama. 
Tabel 4. Intensitas Kerusakan pada Tanaman

\begin{tabular}{lccl}
\multicolumn{1}{c}{ Jati } & & \\
\hline \multicolumn{1}{c}{ Jenis } & $\begin{array}{c}\text { Intensitas } \\
\text { Kerusakan } \\
(\%)\end{array}$ & $\begin{array}{c}\text { Rerata } \\
(\%)\end{array}$ & $\begin{array}{l}\text { Kriteria } \\
\text { Serangan }\end{array}$ \\
\hline $\begin{array}{l}\text { Ulat daun } \\
\text { jati }\end{array}$ & $16-29,66$ & 22,53 & $\begin{array}{l}\text { Rusak } \\
\text { ringan }\end{array}$ \\
Kutu daun & $2,67-9,33$ & 5,7 & $\begin{array}{l}\text { Rusak } \\
\text { ringan }\end{array}$ \\
Belalang & $17,33-33,33$ & 28,93 & $\begin{array}{l}\text { Rusak } \\
\text { sedang } \\
\text { Rusak } \\
\text { ringan }\end{array}$ \\
Kutu putih & $2,33-10,67$ & 6,8 & \\
\hline
\end{tabular}

Meningkatnya populasi hama perusak tanaman jati ditentukan juga oleh kondisi cuaca dan iklim di suatu tempat. Selain itu, tidak semua hama perusak bisa berada pada kondisi cuaca yang sama. Hal ini terlihat pada daerah penelitian, hama ulat daun jati dan belalang ditemukan dalam jumlah yang lebih banyak dibandingkan dengan kedua hama lainnya. Oleh sebab itu, intensitas kerusakan yang disebabkan oleh ulat daun jati dan belalang juga lebih besar.

Belalang diketahui membuat kerusakan yang paling parah pada petak III yaitu sebesar $33,3 \%$. Sedangkan ulat daun membuat kerusakan yang paling parah pada petak I yaitu $29,66 \%$.

Walaupun kerusakan yang ditimbulkan oleh jenis-jenis hama tanaman jati masih tergolong rusak ringan dan rusak sedang, namun sebaiknya hal tersebut jangan dibiarkan. Apabila hal ini tidak diperhatikan dengan serius dan dibiarkan terus menerus, maka kemungkinan akibat yang ditimbulkan akan lebih parah bahkan sampai pada kematian tanaman. Hal tersebut bisa saja terjadi apabila ada faktor lingkungan yang mendukung perkembangan hama-hama itu.

\section{Frekuensi Serangan}

Frekuensi serangan tertinggi pada Tanaman Jati di Kelurahan Klamalu Distrik Mariat Kabupaten Sorong adalah akibat serangan Hama Belalang $(35,2 \%)$ dan yang paling kecil adalah akibat Hama Kutu Daun (4\%).

Tabel 5. Frekuensi serangan hama pada tanaman jati

\begin{tabular}{lccc}
\hline \multicolumn{1}{c}{ Jenis } & $\begin{array}{c}\Sigma \text { Tam yang } \\
\text { Diamati }\end{array}$ & $\begin{array}{c}\Sigma \text { Tan yang } \\
\text { Terserang }\end{array}$ & $\begin{array}{c}\text { Frekuensi } \\
\text { Serangan } \\
(\%)\end{array}$ \\
\hline $\begin{array}{l}\text { Ulat daun } \\
\text { jati }\end{array}$ & 125 & 38 & 30,4 \\
Kutu daun & 125 & 5 & 4 \\
Belalang & 125 & 44 & 35,2 \\
Kutu putih & 125 & 11 & 8,8 \\
\hline
\end{tabular}

Besarnya kerusakan yang terjadi ditentukan oleh banyak faktor, termasuk jumlah serangga hama, cara serangga merusak, bagian tanaman dan tingkat pertumbuhan tanaman serta luas bagian hutan yang dirusak (Sumardi dan Widyastuti, 2007). Selain itu, besar atau kecilnya frekuensi serangan hama terhadap suatu tanaman ditentukan oleh iklim tempat tersebut karena tidak semua hama dapat bertahan pada iklim yang sama. Ada hama yang dapat bertahan pada musim kemarau dan ada yang bertahan pada musim hujan Kegiatan pemeliharaan tanaman secara intensif dapat memperkecil frekuensi serangan hama. Dengan demikian, kurangnya kegiatan pemeliharaan tanaman jati dapat menyebabkan daya tahan tanaman pun kecil, sehingga serangan hama atau penyakit dapat saja terjadi sewaktu-waktu. Selain itu, pertumbuhan tanaman jati akan semakin terancam apabila kegiatan pengendalian hama tidak dilakukan, 
sehingg adapat mengakibatkan penyebaran hama semakin meluas.

\section{KESIMPULAN}

Beberapa jenis hama yang menyerang tanaman Jati di Kelurahan Klamalu Distrik Mariat Kabupaten Sorong, yaitu belalang, kutu daun, ulat daun jati, dan kutu putih, dengan ratarata intensitas kerusakan akibat serangan hama belalang 28,93 \% tergolong kriteria rusak sedang, hama ulat daun $22,53 \%$ tergolong kriteria rusak ringan, hama kutu putih 6,8\% tergolong kriteria rusak ringan dan hama kutu daun $5,7 \%$ tergolong kriteria rusak ringan. Sementara itu, frekuensi serangan Hama Belalang sebesar 35,2\%, Hama Ulat Daun Jati 30,4\%, Hama Kutu Putih 8,8\% dan Hama Kutu Daun sebesar $4 \%$.

\section{DAFTAR PUSTAKA}

Da lopes Y, F. 2017. Panduan Bergambar Pengenalan ordo Serangga Hama. Jurusan Manajemen Pertanian lahan Kering (MPLK) Politeknik Pertanian Negeri Kupang

Herdiana N. 2010. Potensi Serangan Hama Tanaman Jati Rakyat dan Upaya Pengendaliannya Di Rumpin Bogor.Jurnal penelitian Hutan Tanaman Volume 7 Nomor 4 Oktober 2010, Hal 177-185

Hidayat R, Yusran dan Sari I. 2014. Hama Pada Tegakan Jati (Tectona grandis, L.f) di Desa Talaga Kecamatan Dampelas Kabupaten Donggala. Warta Rimba Volume 2 Nomor 1 Juni 2014, Hal 24-34

Indriyanto. 2008. Ekologi Hutan. Bumi Aksara. Jakarta

Nair KSS (ed.). 2000. Insect pests and diseases in Indonesian forest: an assessment of the major threats, research efforts and literature. Center for International Forestry Research. Bogor. ISBN 979-8764-52-8

Pratiwi T, Karmanah dan Gusmarianti R. 2012. Inventarisasi Hama dan Penyakit Tanaman Jati Unggul Nusantara Di Kebun Percobaan Cogrek Bogor. Jurnal Sains Natural Universitas Nusa Bangsa Volume 2 Nomor 2 Juli 2012, Hal 123-133

Pracaya. 2003. Hama dan Penyakit Tanaman. Penebar Swadaya. Jakarta

Siregar, A. Z. 2008. Hama-hama Dominan Jati (Tectona grandis). Departemen Hama dan Penyakit Tumbuhan Fakultas Pertanian Universitas Sumatera Utara

Sumardi dan Widyastuti S.M. 2007. Dasar-dasar Perlindungan Hutan. Gadjah Mada University Press. Yogyakarta

Umarela U dan Karepesina S. 2011.Inventarisasi Hama Pada Areal Tanaman Jati Di Desa Liang Kecamatan Salahutu. Jurnal Bimafika Volume 2 Nomor 2, Hal 235-238 